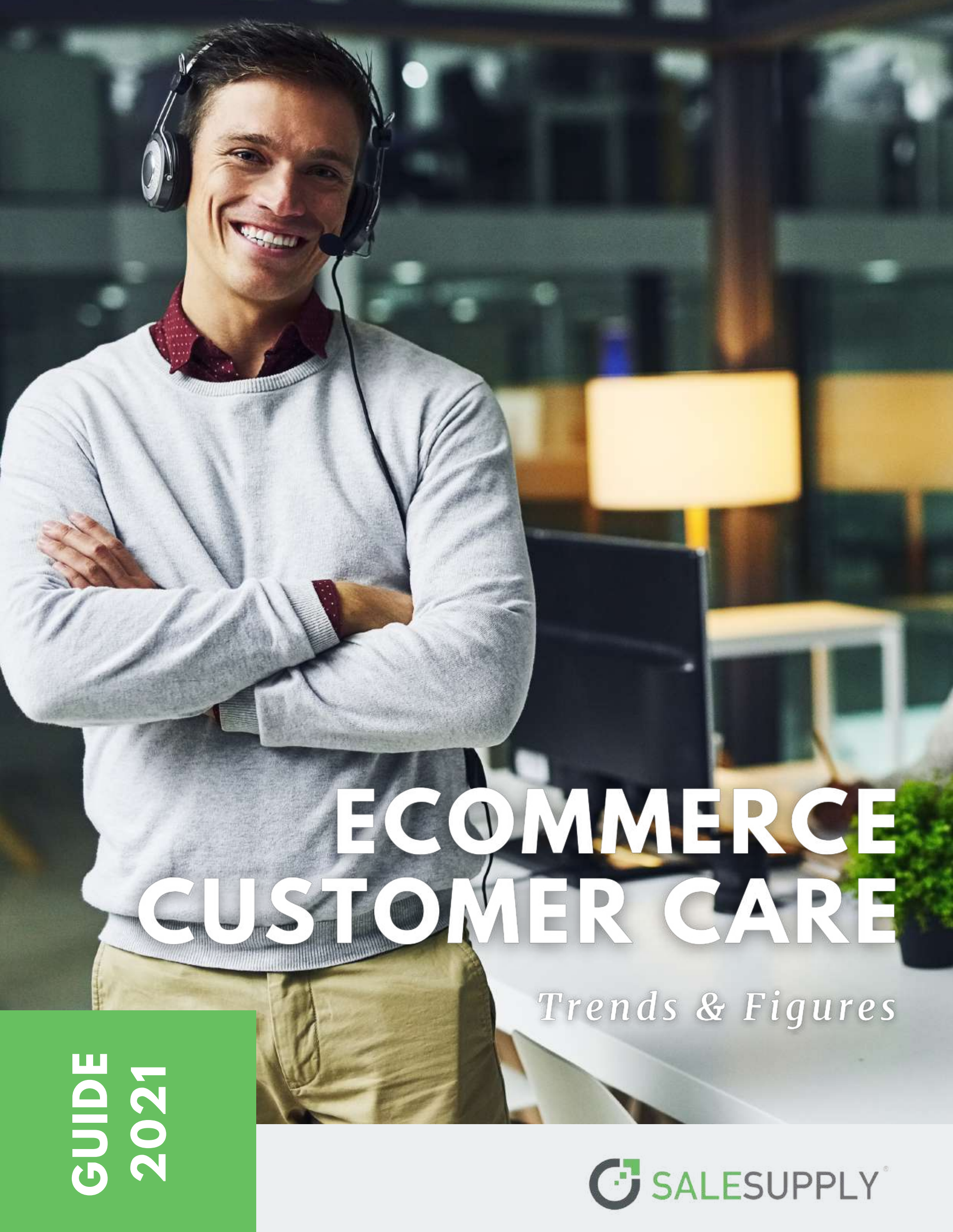




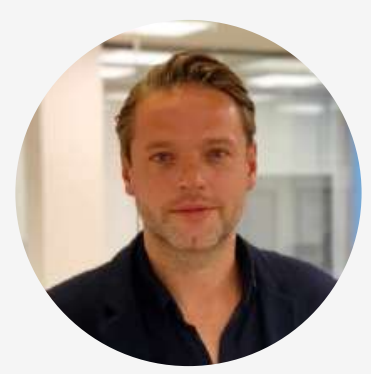

FOREWORD

2020 was a historic year in all respects and that was especially true for the ecommerce sector. COVID-19 has accelerated both the rate of e-commerce penetration and sales growth in virtually every category, obviously with the exception of travel/tourism and events.

This unprecedented online growth brought retailers both opportunities and challenges. Customer service teams were put under substantial pressure, and the return numbers also skyrocketed.

This led to an upsurge in some amazing innovations in the online shopping experience, where staff used technology to try to give consumers the most realistic and personalised online shopping experience imaginable.

The important role of customer service in these online shopping experiences is particularly promising. This means that, as a sector, we see customer service less and less as a cost item and more and more as a pillar of revenue growth.

Even at the beginning of 2021, e-commerce is still the single / most prominent retail channel in a lot of countries. Whether this will remain the case throughout the year remains to be seen. One thing is certain as far as I am concerned. If, as a sector, we also want to hold on to our (new) e-commerce end consumers after the pandemic, we must remain focused on offering the ultimate online shopping experience. A professional and well-prepared customer service is indispensable in this.

In this whitepaper, we have taken a closer look at Customer Care per segment and country, so as to offer some insights and help you create the ultimate customer care experience.

Have fun reading it!

Hans Siebum

Managing Director Global Salesupply 


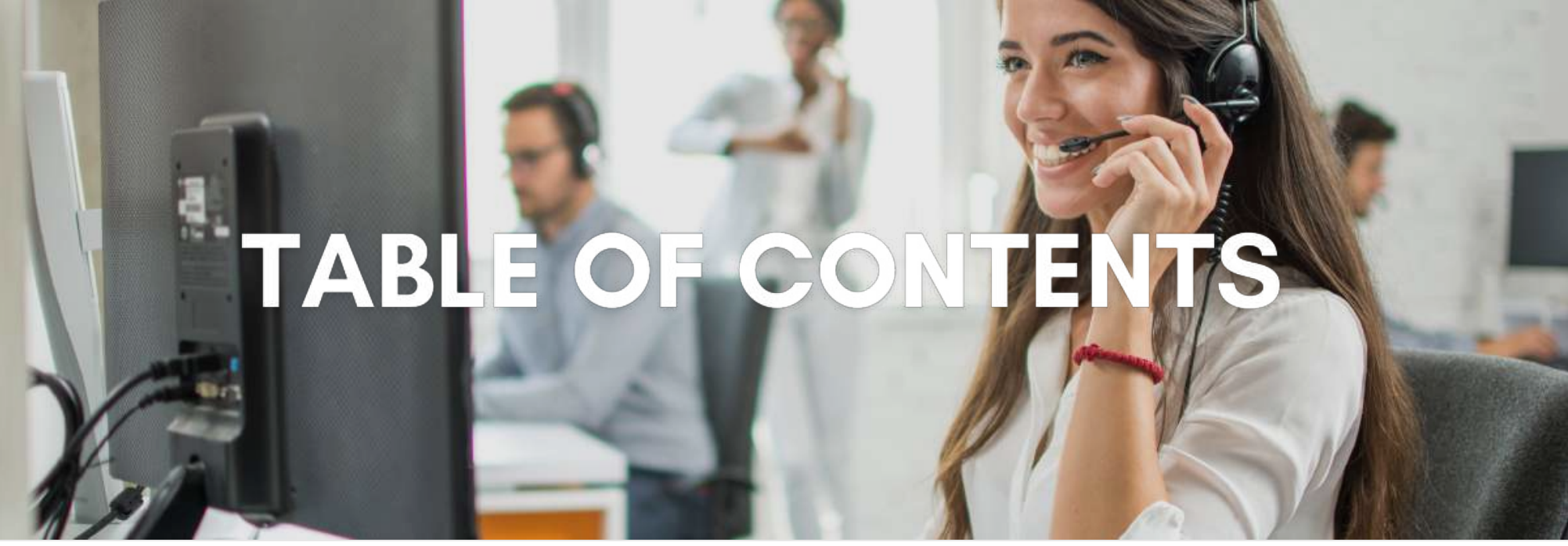

Facts: The importance of Customer Service

02 Creating an online in-store experience

03 E-commerce Customer Care Segment Overview

- Fashion

- Electronics

- Home \& Garden

- Sports \& hobbies

- Personal care

- B2B

04 Social media as a service channel

05 E-commerce Customer Care Country overview

- The Netherlands

- Germany

- United Kingdom

- Italy

- France

- Spain

- Poland

- United States

03 Bibliography 


\section{FACTS: THE IMPORTANCE OF CUSTOMER SERVICE}

In a remarkable time when shopping online is now more normal than offline, people are expecting at least the same customer service online. $\mathbf{5 9} \%$ of consumers indicate that they have raised their customer service standards during the COVID pandemic. (1)

\section{WHAT DO CUSTOMERS EXPECT FROM CUSTOMER SERVICE?}

- Speed: $83 \%$ of consumers expect to speak to someone on the first attempt

- Omnichannel: $76 \%$ expect the option of being able to choose between different contact channels. The choice of channel often depends on the question itself

- Personalization: $65 \%$ of consumers expect all agents to have access to the same information so that they do not have to explain their situation all over again once they are redirected

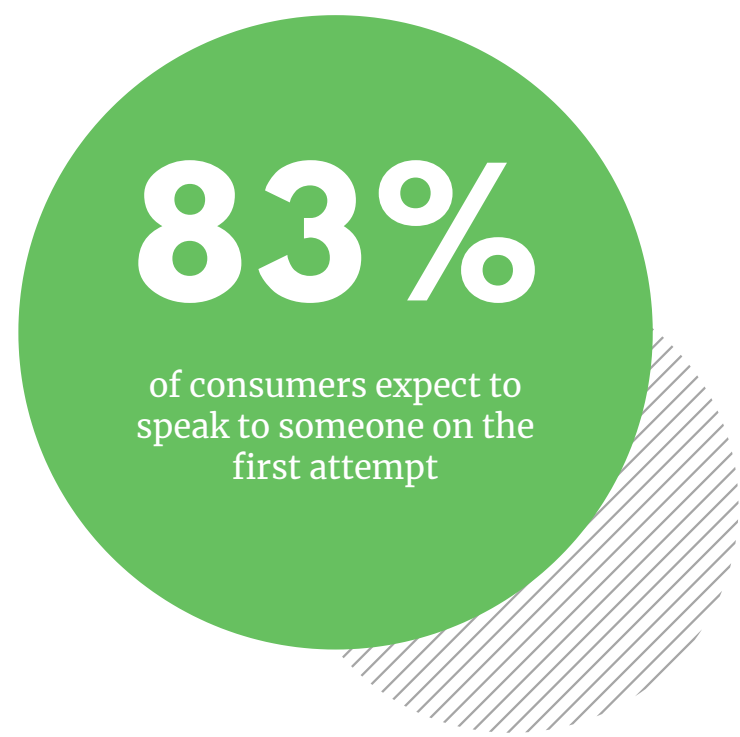

\section{THE ADDED VALUE OF CUSTOMER SERVICE IN FIGURES}

- $91 \%$ say they are willing to use a webshop more often after a positive experience

- $77 \%$ share a positive experience

- $73 \%$ of consumers remain loyal to a company whose agents are friendly (2)

- $70 \%$ would spend more at a webshop that has good customer service

- $55 \%$ of consumers say that they would become a customer at your webshop because of its reputation for good customer service (3)
- $66 \%$ will switch to a competitor if they are treated in an impersonal manner

- $60 \%$ will not return to your company after one bad experience

- $50 \%$ will tell others about a bad experience

- $41 \%$ state that they would spend less at your webshop after a bad experience 


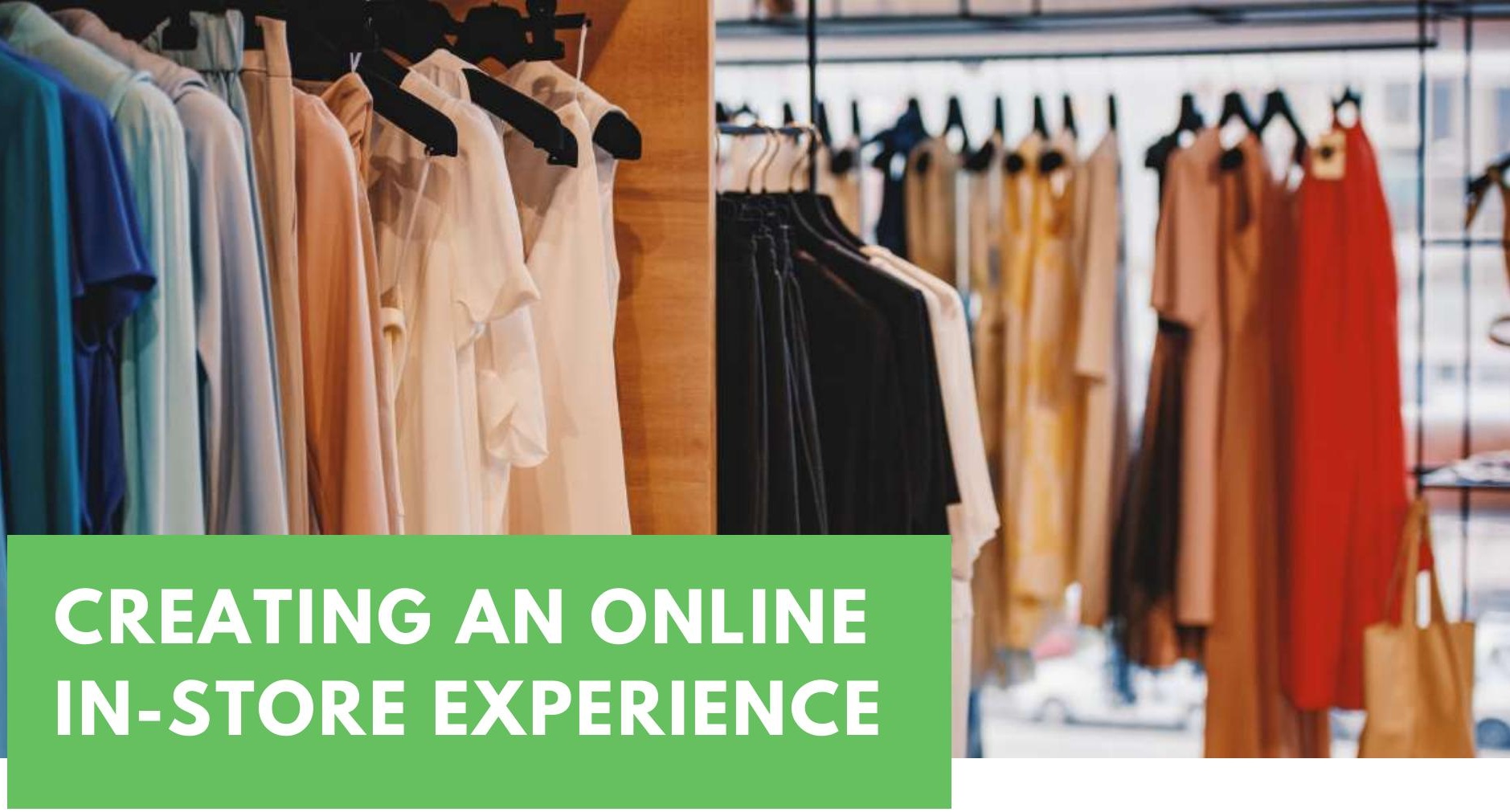

The shopping experience is becoming increasingly more important in online retail. That consumers are missing out on style advice (fashion) or the ability to see and touch the product (furniture) is a major problem and leads to returns. More and more retailers are using technology to simulate online in-store shopping experiences. In particular, AI is often used for this purpose.

Below is a selection of successful applications.

\section{ONLINE SHOPPING WITH}

\section{PERSONAL SERVICE}

\section{OMODA PERSONAL SHOPPER}

Omoda has chosen to continue offering personal styling advice during the corona crisis. Customers are given tailor-made styling advice by means of a virtual tour of the shop.

Shoppers can schedule an online appointment via the webshop. They can choose between Facetime, Whatsapp video calling or Google Hangout. (4)

\section{PRECISION CAMERA AND VIDEO VIRTUAL SHOWROOM}

Precision Camera and Video sells all products related to photography, from cameras and lighting to microphones and drones. The American electronics shop offers shoppers the option of receiving one-on-one assistance from home. Shoppers can book appointments within certain timeframes.

During these appointments, the customer talks with a shop employee via a webcam. In this way, customers receive the expert advice they are used to, but safely from home. (5) (6) 
THE HELP OF AUGMENTED

\section{REALITY (3D)}

\section{TENTH STREET HATS}

\section{AUGMENTED REALITY}

Tenth Street Hats is a webshop for hats. They offer their shoppers a special experience with the 'Try it on in AR' tool. Smartphone and desktop users can try on hats in 3D via their camera. With spectacular results, thanks to the tool, the conversion rate on the webshop rose by $33 \%$ ! (7)

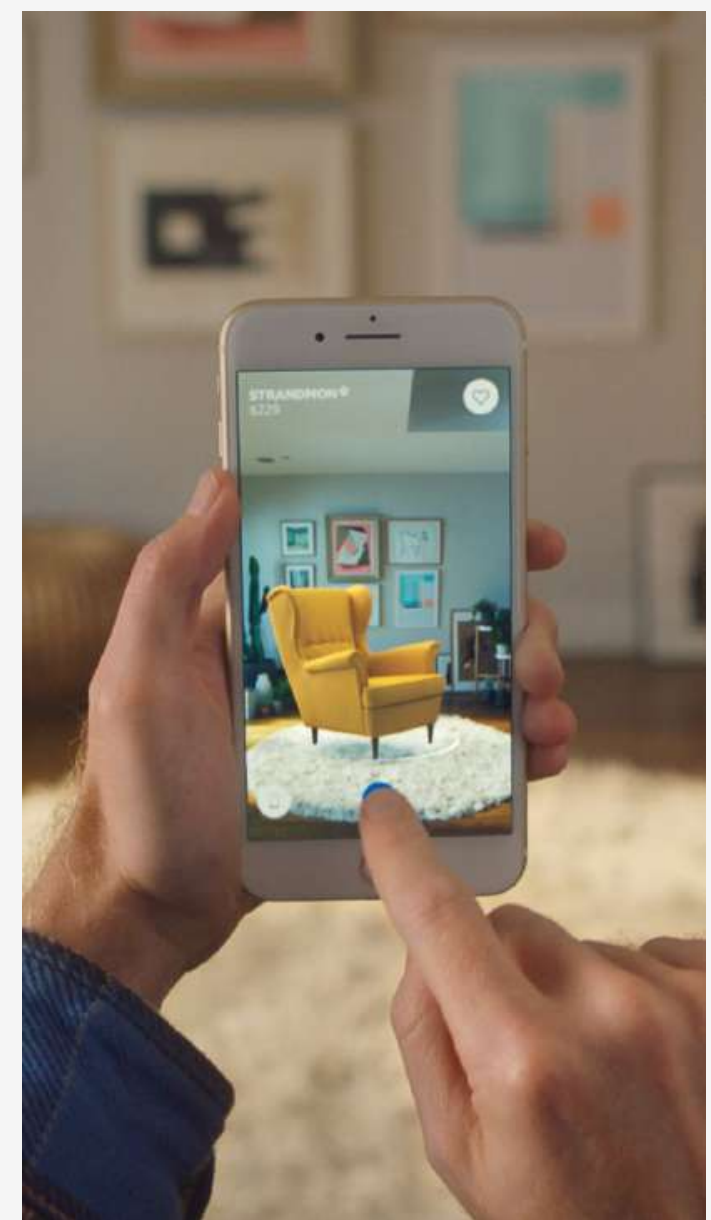

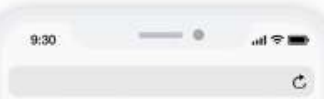

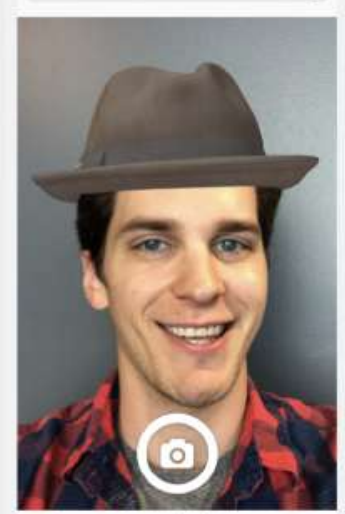

ETENTHSTREET. vatual taron TENTHSTRET

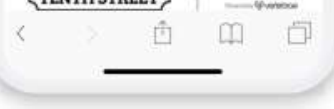

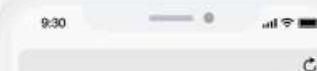

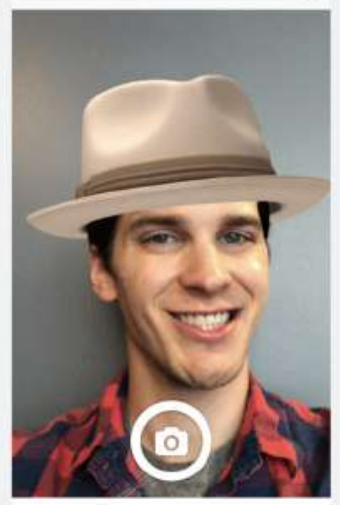

TENTH STREET. VIRTUAL TRYON (4) प1

\section{IKEA AUGMENTED REALITY FURNITURE}

IKEA was relatively early in introducing an AR tool. By means of the 'IKEA Place' app, customers can view the entire furniture collection and find inspiration. On the product pages, you can choose to project the furniture at the correct scale in $3 \mathrm{D}$ in your home. Within the furniture segment, AR has the following advantages:

- AR increases consumers' confidence in making a choice.

- AR attracts more consumers

- AR ensures fewer returns

- The WOW factor of AR; the tool gives customers a unique online shopping experience that sets you apart from competitors. (9) 



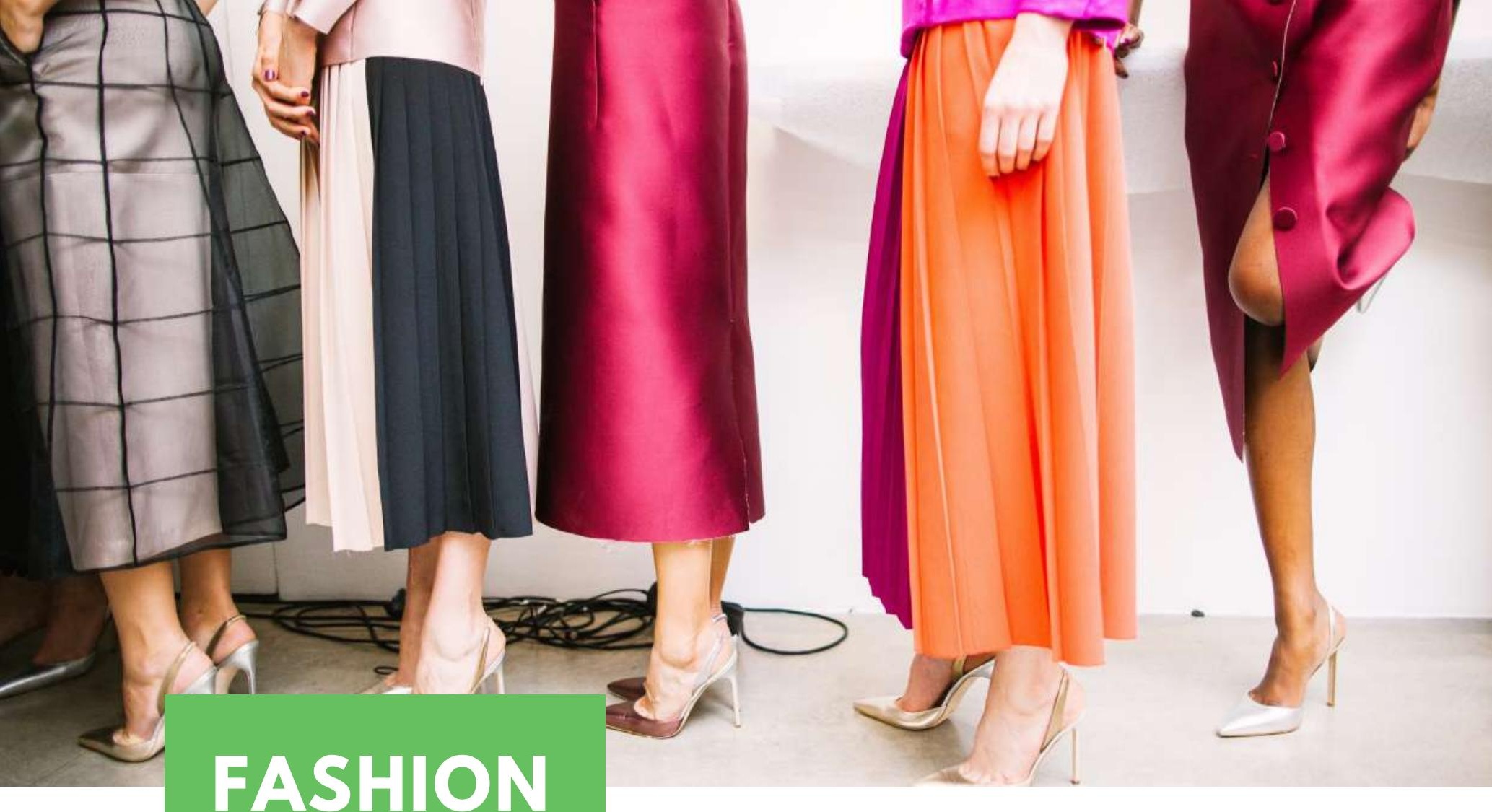

\section{FASHION}

\section{ADVICE BASED ON CUSTOMER DETAILS}

More and more fashion retailers are registering supplementary relevant

information from customers in their system

- with the customer's explicit consent, of course. The shoe size, waist measurements, and the favourite colours of the customer are stored.

This enables customer service staff to give each customer personal style advice down to the smallest detail. cutting edge of customer service. The Tory

Burch customer service is made up of genuine fashionistas. They are not just there to answer questions about a delivery, they really go the extra mile. The fashionistas of Tory Burch offer style advice and help customers find the right outfit for every occasion. 


\section{ELECTRONICS}

By $2021,38 \%$ of all purchases in the electronics sector are expected to take place online. The percentage of internet purchases combined with the technical nature of the products means that a well-informed customer service is an absolute must in this industry. (12)

\section{RETURNS}

Customer service in the electronics industry is often contacted with regard to return requests. Frequently cited reasons are:

- The customer had different expectations

- The product was received in a damaged state

- The product was found cheaper elsewhere

CUSTOMER SERVICE PLAYS AN IMPORTANT ROLE IN REDUCING RETURNS IN THE ELECTRONICS INDUSTRY
According to research by Techsee, $\mathbf{7 2} \%$ of consumers say that good customer service helps to prevent returns.

$\mathbf{7 1} \%$ of consumers say that an agent with a great deal of product knowledge could change their mind about returning a product by explaining how to install or use it.

$\mathbf{4 5 \%}$ of consumers say that product videos in which experts explain everything about a product can be helpful.

$\mathbf{4 4} \%$ of consumers indicate that a live personal video session with an expert can help prevent returns. In this type of video session, the expert can explain everything about the product so that the product will not fail to meet the customer's expectations. Experts can also help customers with installation or use. (13) 



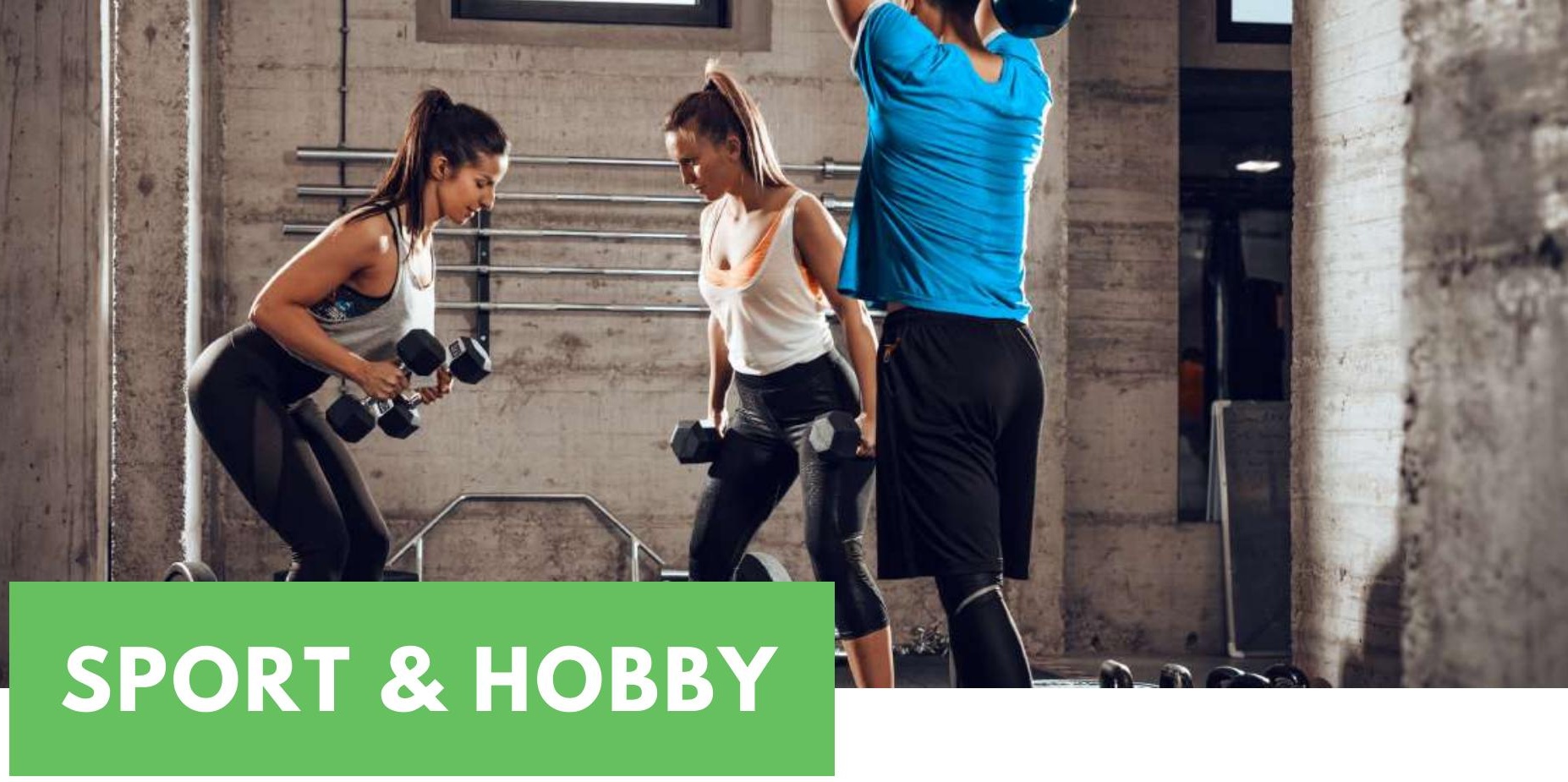

The online sports and hobby segment grew enormously during the corona pandemic. Gyms and other sports facilities closed down and the only way to exercise was from home. People exercised a lot less at the beginning of the pandemic, but this quickly changed - partly due to the personal initiatives of sports and fitness brands.

\section{NIKE 'ATHLETES FOR ATHLETES}

Nike's support teams on social media are known everywhere. The customer service account 'NikeService' is especially successful on Twitter. This branch of the sports brand's customer service offers $24 / 7$ support to customers in seven languages. (15)

Nike has also been busy staying connected with consumers during the lockdowns. The sports brand soon noticed a huge growth in the use of their sports apps. To boost engagement and make exercise more enjoyable, Nike employed their sponsored athletes to demonstrate home workouts. (16)

\section{FITBIT COACH}

Fitness and electronics company Fitbit also responded to the new situation in an intensive way and offered numerous initiatives to support its customers. Fitbit offered their app users 90 days of free use of all premium services.

These included the 'Fitbit Coach' services. With this service, customers can view personalised workouts for free. These workouts are customised to match any personal information Fitbit has on the customer.(17) (18)

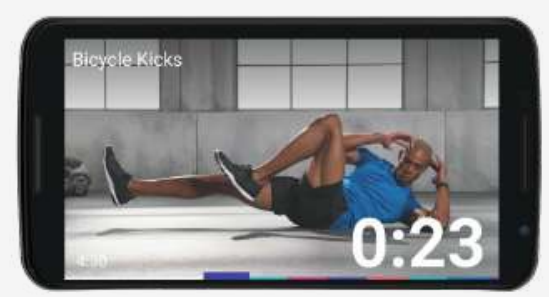




\section{PERSONAL CARE}

The name of the sector says it all: personal care products are extremely personal. Purchases depend on, among other things, different skin types and styles. Personalisation is tremendously important here.

In the personal care segment in 2021, $17 \%$ of all 1.4 billion purchases are expected to be made online. Online customer service therefore absolutely merits attention in 2021. (19)

\section{CUSTOMER SERVICE IS KEY: GLOSSIER 'GTEAM'}

Glossier is an example of an online beauty brand that pays a lot of attention to customer service. In addition to email and phone, the brand is also in direct contact with customers through social media.

For Glossier, customer service is not an extra business expense, it is one of the pillars of their strategy. The customer service team is a customer experience team.

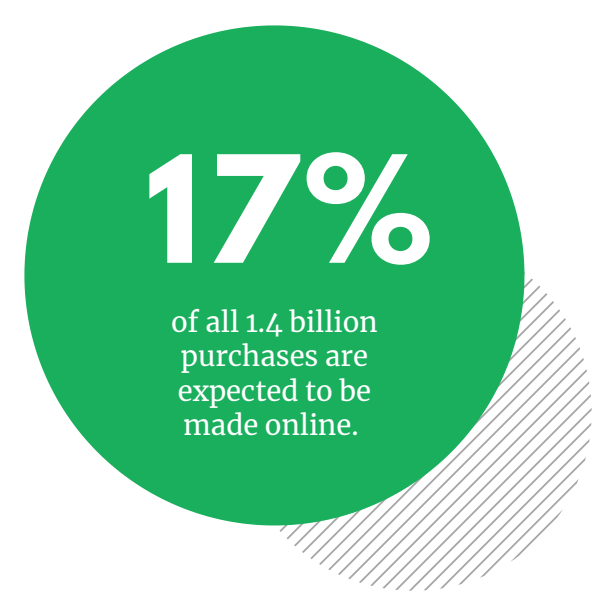

They adapt their language to the target group and provide personal advice. A customer with a question about a certain foundation or bronzer, can, for example, send a selfie to the Glossier account, and one of the employees will help the customer with the right product.

The 'gTeam' is in close contact with product development and marketing. New products are regularly added thanks to feedback and the wishes of customers. Customer service is therefore key to the Glossier organisation.(20) 


\section{B2B}

Business consumers are used to the omnichannel experiences offered by B2C. Consequently, business consumers expect more and more from B2B companies. In addition to an omnichannel approach, customer experience optimisation is principally found in balancing self-service and full-service.

Within B2B, live chat, voice chat and emails are the most common touchpoints for customers. $55 \%$ of B2B customers would welcome an option for real-time communication with an agent. This can be done in the form of live chats or video calls. (21)

\section{THE ESSENCE OF CUSTOMER}

\section{SERVICE IN B2B}

That good customer service is of great value is obvious. In the B2B market, this is even more important than in the $\mathrm{B} 2 \mathrm{C}$ market: $\mathbf{7 9} \%$ of business customers indicate that they have made purchase decisions based on the quality of customer service.

\section{HIGH DEMAND FOR} PERSONALISATION
Within B2B customer service, the demand for personalisation is high. B2B customers usually pay more than $\mathrm{B} 2 \mathrm{C}$ customers and expect the quality of customer service to reflect this. $74 \%$ of business customers expect all agents to have the same personal information. However, $\mathbf{6 0} \%$ still often have to repeat personal information to different agents. (22)

\section{DIFFERENCES IN}

\section{EXPECTATIONS WHEN IT COMES TO B 2B AND B 2C CUSTOMER SERVICE}

\begin{abstract}
A B2B transaction often signals the start of a relationship, which is why more post-purchase support is preferable. Whereas in $\mathrm{B} 2 \mathrm{C}$, a customer service agent only has to satisfy one person, a B2B agent has to satisfy an entire company. $76 \%$ of $\mathrm{B} 2 \mathrm{~B}$ purchasers expect a company to be able to meet their specific needs and expectations.
\end{abstract}

$69 \%$ of business consumers expect to be approached proactively compared to $54 \%$ in B2C. $67 \%$ expect that specific needs should actually be anticipated, compared to $54 \%$ in $\mathrm{B} 2 \mathrm{C}$. 


\section{SOCIAL MEDIA AS A SERVICE CHANNEL}

Social media is being used more and more as a customer service Mrchannelint. $76 \%$ of the people who contact a company via social media do so for service or support. (23) The most frequently used social channels for customer support are Facebook (Messenger), WhatsApp, Instagram and Iwitter.

\section{GENERATIE Z}

Social media is a popular service channel amongst consumers under 25 , with $32 \%$ of the target group viewing it as their favourite service channel. (24)

Almost all companies are active on social media. Often, the responsibility for these channels lies with marketing teams.

Many success stories involving the use of social media as a channel come from companies that have also dedicated their customer service teams to social media. These companies frequently use a separate account for this service as well. As an example, @Salesupply becomes@SalesupplyHelp,or @SalesupplySupport

\section{ROOM FOR IMPROVEMENT}

Yet there is still room for improvement, as various studies have shown that consumers expect more from customer service on social media. For instance, $49 \%$ of consumer complaints on social media are ignored by companies. (25) 


\section{SOCIAL MEDIA AS A SERVICE CHANNEL}

\section{RESPONSE TIMES}

Just like e-commerce, social media is not tied to working hours. $57 \%$ of customers expect a response on weekends and in the evening just as promptly as during office hours. (26)

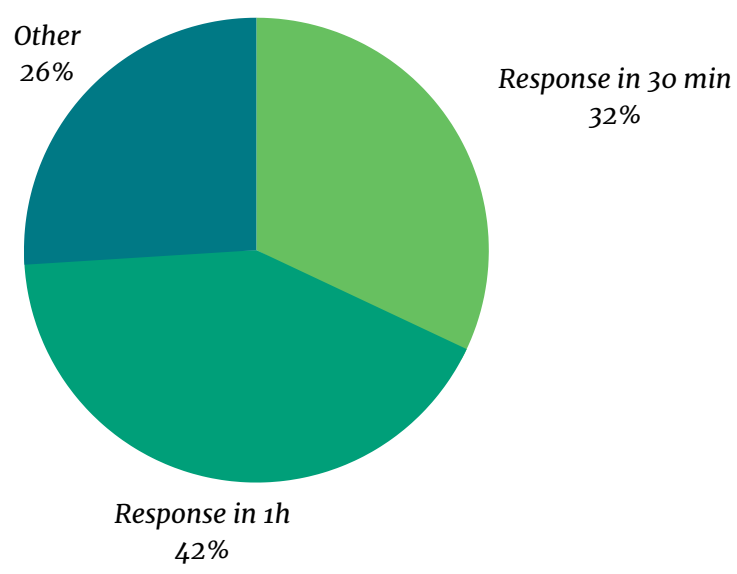

Not all companies can live up to this expectation. This is also shown by a survey on Facebook Messenger as a contact channel:

- $32 \%$ of 251 companies that were surveyed responded within the preferred 1st hour. Of these, $11 \%$ responded within 1 minute through the use of an automated (chatbot) system.

- As many as $45 \%$ of the webshops only responded to Facebook Messenger messages after five days or more (27)

\section{FACEBOOK QUALITY MARK}

Webshops that respond to $90 \%$ of the messages and have a response time of less than 15 minutes, receive a 'Very Responsive to Messages' badge from Facebook, this badge instils consumer confidence in your shop.

\section{$=$ Very responsive to messages \\ $100 \%$ response rate, 5 -mins response time}

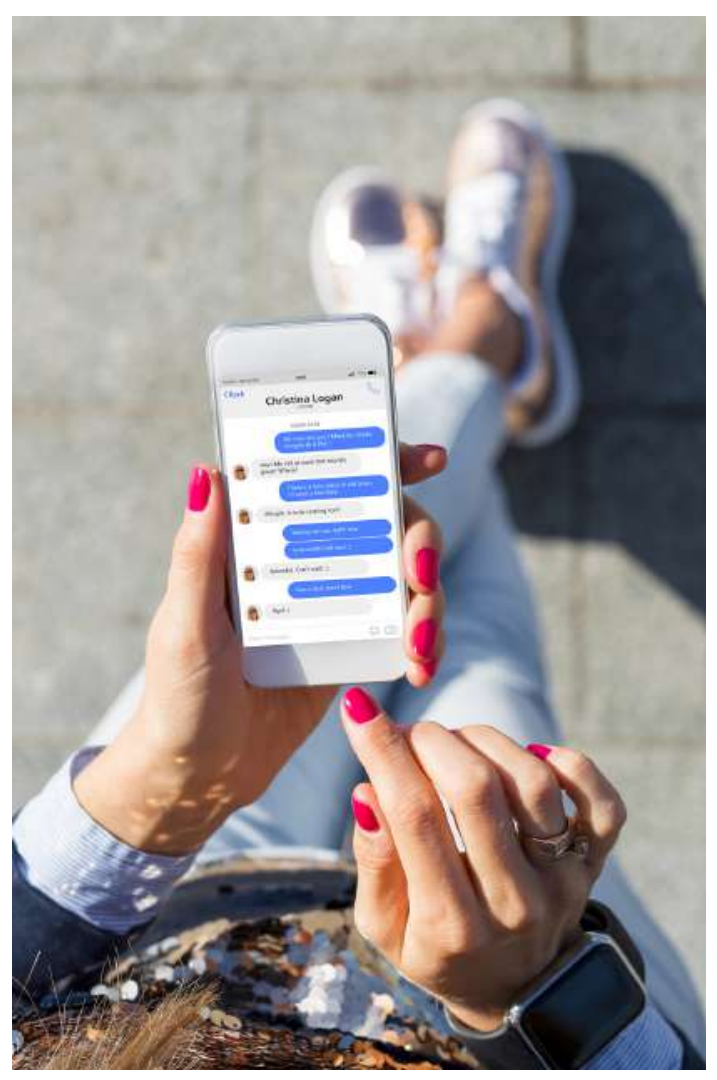





\section{THE NETHERLANDS}

\section{PREFERRED CONTACT CHANNELS}

In the Netherlands, the most frequently used service channels are telephone and email. In addition, more and more customers expect companies to be available on their preferred communication channels. In addition to the largest social media channels WhatsApp, Facebook and Instagram, customers also want accessibility on Twitter and SMS. (28)

Top three favourite contact channels

- Telephone

- Email

- Chat (live chat \& social media)

\section{EXPECTATIONS OF DUTCH CONSUMERS}

Among Dutch consumers, expectations are high when it comes to customer service interaction. The Dutch are looking for personalisation and empathy. Consumers expect that the different agents they speak to, know about their question or problem. An integrated omnichannel network is therefore indispensable in the Netherlands.

The biggest source of dissatisfaction for Dutch customers regarding customer service is being frequently redirected. (29)
DUTCH CONSUMERS EXPECT CUSTOMER SERVICE TEAMS TO HAVE, AMONG OTHERS, THE FOLLOWING DETAILS:

- $52 \%$ : all recent information on the last order

- 50\%: information on all previous orders

- $20 \%$ : product advice based on their order history (30)

\section{THE MOST FREQUENTLY USED SOCIAL MEDIA PLATFORMS IN THE NETHERLANDS (31)}

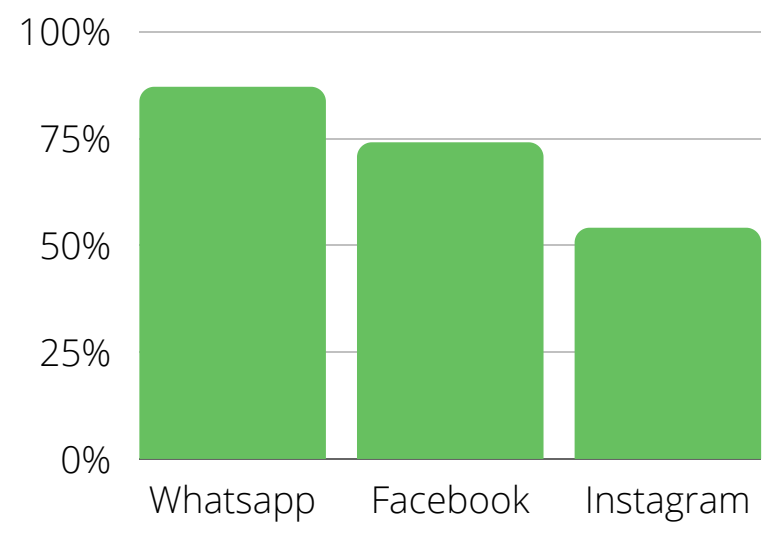




\section{GERMANY}

\section{PREFERRED CONTACT CHANNELS}

In Germany, customer service is most

frequently contacted by telephone and email.

For both channels, 56\% choose it as their

favourite or one of their favourites. Online chat

is also frequently mentioned by $23 \%$. (32)

\section{CUSTOMER SERVICE IN}

\section{GERMANY? THIS IS SOMETHING THAT IS NOT DONE}

- Only having phone and mail as channels. Omnichannel is a must

- Lengthy response times. German consumers also want a prompt answer to their question.

- German customers find that talking to someone who does not know what he or she is calling about is unacceptable. Centrally stored customer information is a must. (33)

\section{WHAT DO GERMAN}

\section{CONSUMERS VALUE MOST?}

- $\mathbf{5 2} \%$ : Friendliness and helpfulness of agents

- 38\%: Prompt service

- $32 \%$ : Being kept informed during every step of the process

\section{THE MOST FREQUENTLY USED SOCIAL MEDIA PLATFORMS IN GERMANY}

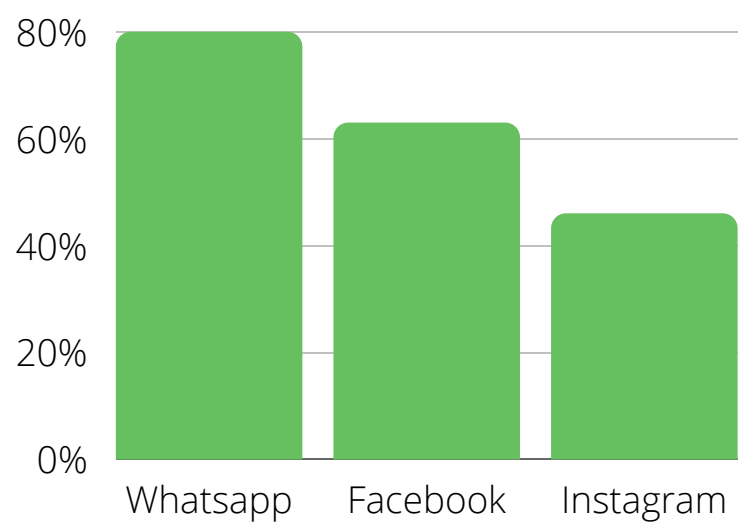

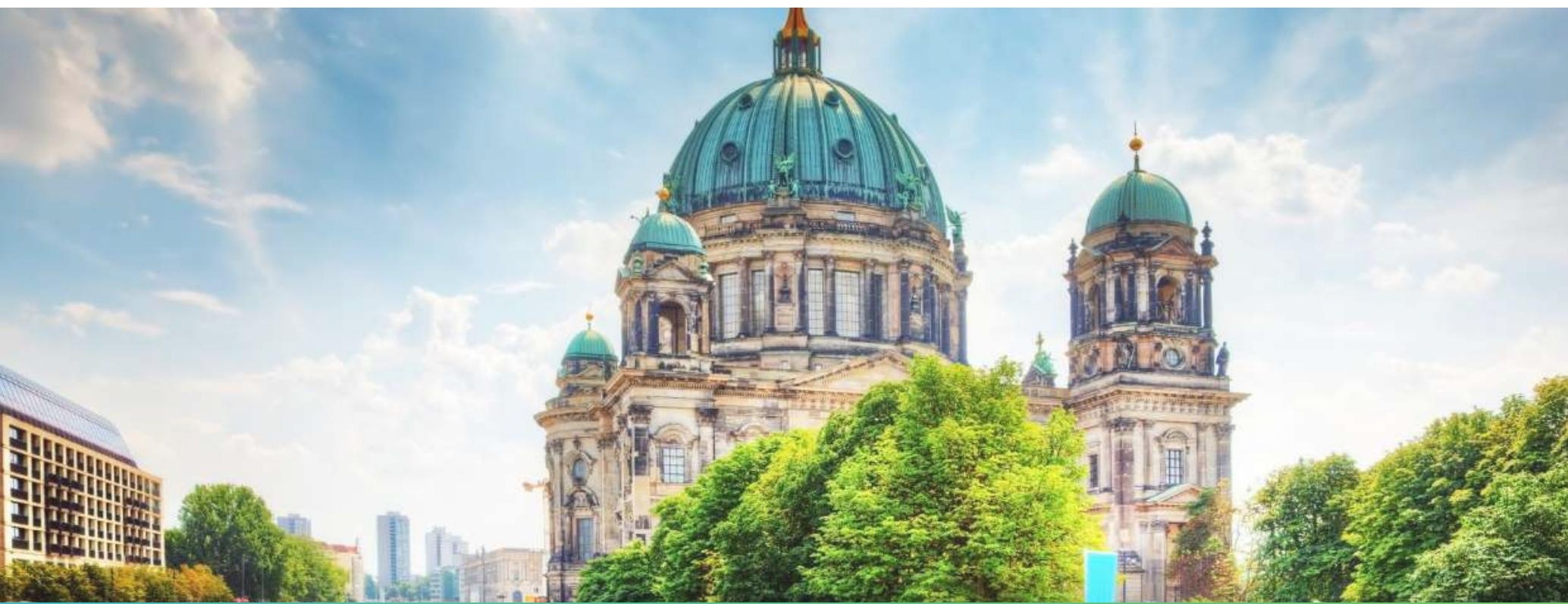




\section{来 UNITED KINGDOM}

\section{PREFERRED CONTACT CHANNELS}

In the United Kingdom, consumers prefer to be contacted by phone, $\mathbf{5 8 \%}$ rate this as their favourite option. After that, email is the most selected option, followed by online chat. $46 \%$ prefer to contact customers via online chat options such as live chat or social media.

\section{CUSTOMER SERVICE WITHIN 5 MINUTES}

The demand for speedier customer service is rising, also in the UK. A survey by Eptica (34) reveals what British consumers expect from customer service within 5 minutes:

- $\mathbf{5 2} \%$ - wants the phone to be answered within 5 minutes

- $48 \%$ - will end a chat session if their problem is not resolved within 5 minutes

- $37 \%$ - will end a phone call after 5 minutes if their problem is not resolved

- $\mathbf{2 8 \%}$ - expect a reply on Twitter within 5 minutes

- $25 \%$ - expect a reply from Facebook within 5 minutes

- $16 \%$ - want a full reply to their email within 5 minutes
WHAT DO BRITISH

\section{CONSUMERS VALUE MOST?}

- 65\%: Friendliness and helpfulness of agents

- 49\%: Prompt service

- $\mathbf{4 2} \%$ : Being kept informed during every step of the process

\section{THE MOST FREQUENTLY USED SOCIAL MEDIA PLATFORMS IN GREAT BRITAIN}

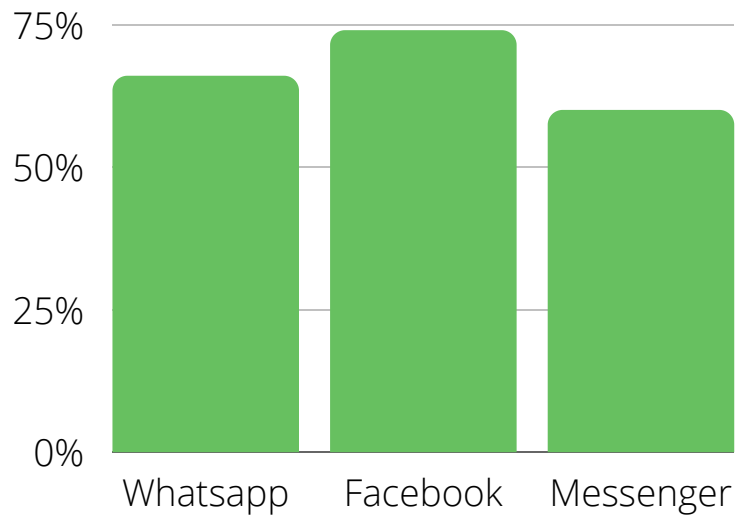

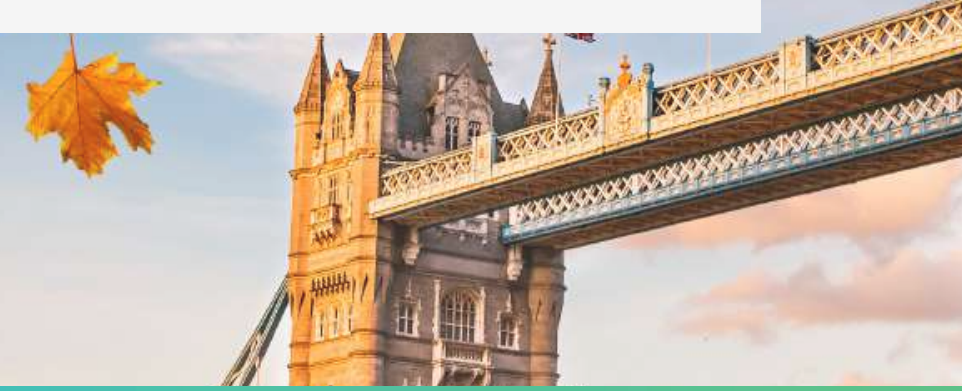

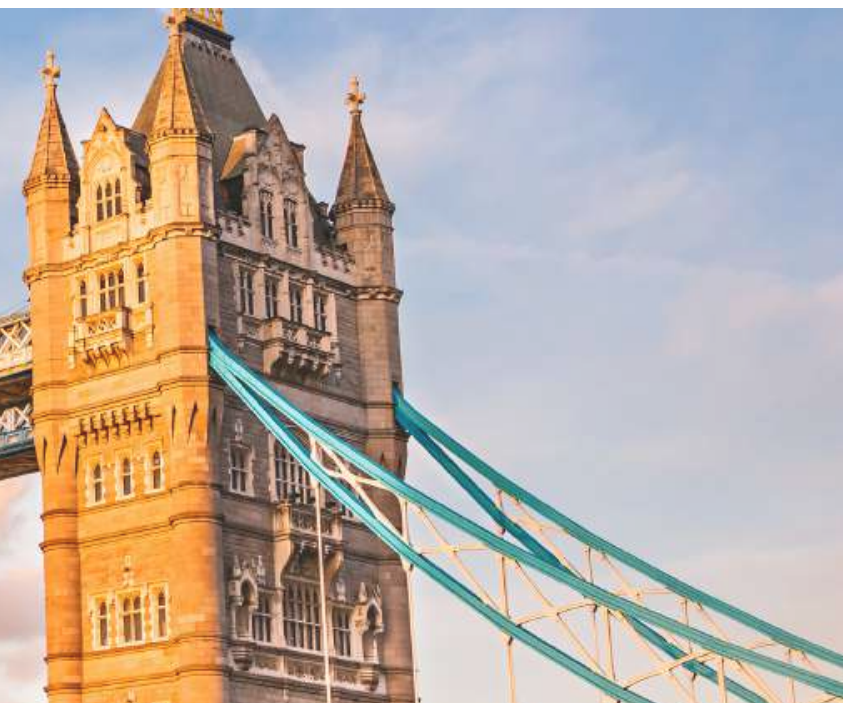




\section{() ITALY}

\section{PREFERRED CONTACT CHANNELS}

The Italian consumer prefers email over

telephone as their favourite customer service

channel. Alongside this, the popularity of

online chat options is growing. (35)

The favourite contact channels:

- Email

- Telephone

- Online chat (live chat \& social media)

\section{THE MOST FREQUENTLY USED SOCIAL MEDIA PLATFORMS IN ITALY}

\section{$100 \%$}

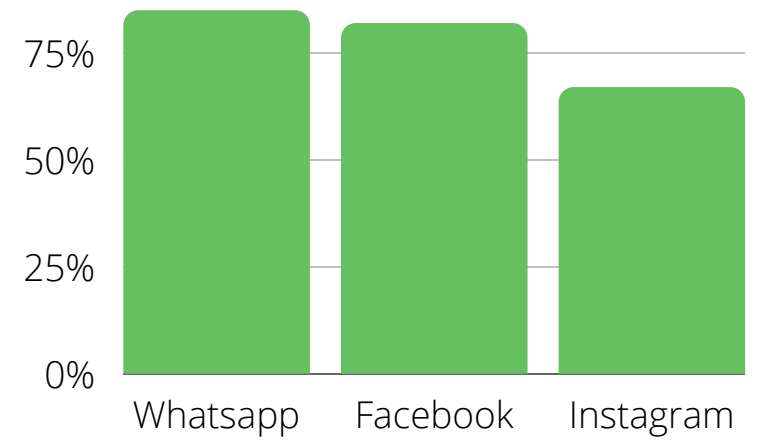

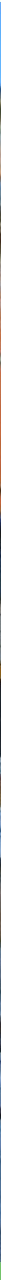




\section{() FRANCE}

\section{PREFERRED CONTACT CHANNELS}

The majority of French consumers use a variety of contact channels for customer service. They prefer to be contacted by telephone, followed by email. Online chat options such as live chat and social media are becoming increasingly popular and $\mathbf{2 1} \%$ of consumers identify them as their favourite.

\section{THE BIGGEST SOURCES OF IRRITATION}

During contact with customer service,

French consumers are irritated by (36):

- $47 \%$ being redirected to another agent and having to repeat the question again.

- $\mathbf{4 1 \%}$ being kept on hold for a long time

- $30 \%$ slow response during a chat session

\section{WHAT DO FRENCH}

\section{CONSUMERS VALUE MOST?}

- 46\%: Prompt (customer) service with a good solution

- 40\%: Friendliness and helpfulness of agents

- $29 \%$ : Being kept informed during every step of the process

\section{THE MOST FREQUENTLY USED SOCIAL MEDIA PLATFORMS IN FRANCE}

\section{$100 \%$}

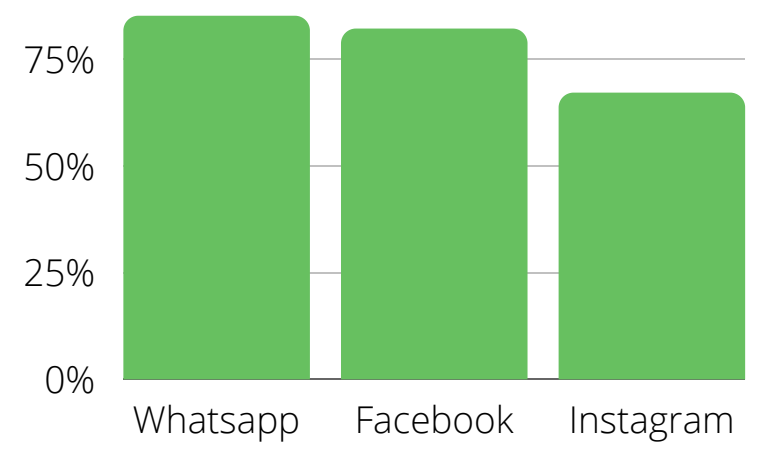

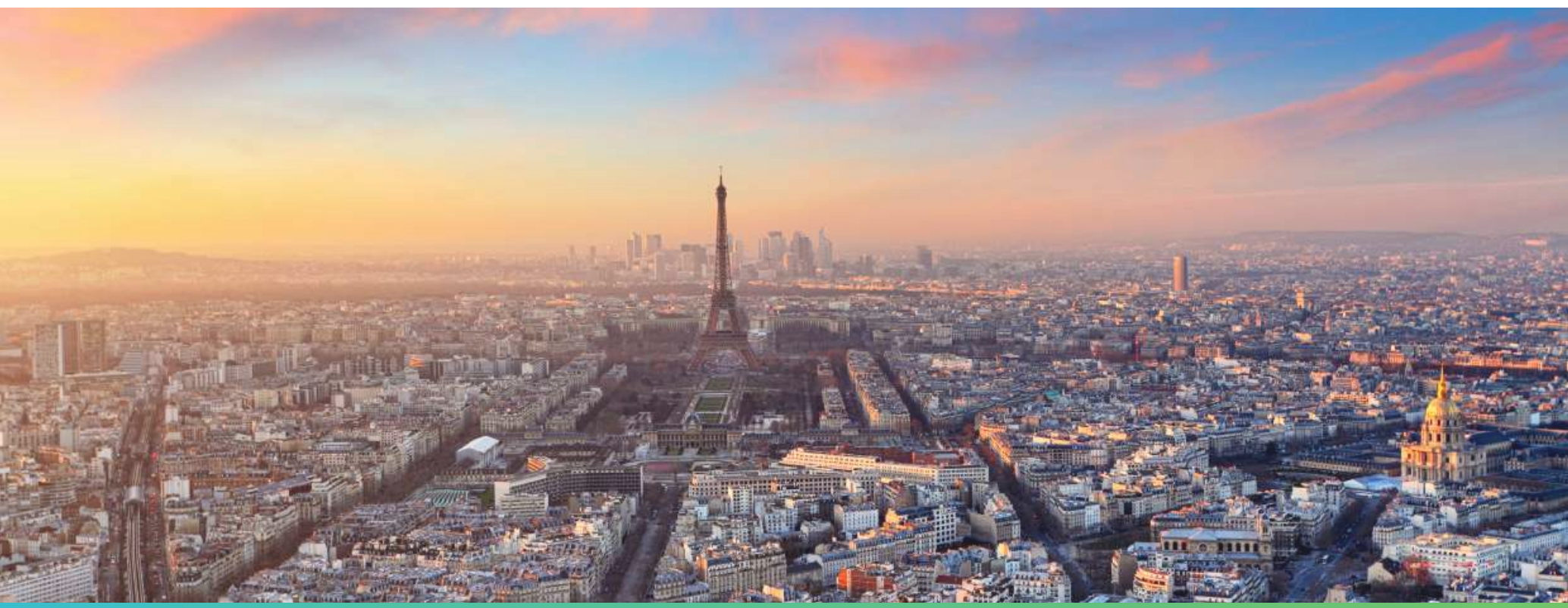




\section{SPAIN}

\section{PREFERRED CONTACT CHANNELS}

Spanish consumers overwhelmingly opt for telephone (66\%) and email (60\%) to contact customer service.

Online chat (social media, live chat) is only specified as an option by $11 \%$. (37)

\section{THE BIGGEST SOURCES OF IRRITATION}

During contact with customer service, Spanish consumers are irritated by (38)

- Being put on hold

- Negative use of language

- Being redirected

- An agent who acts defensive

- Being redirected to the website

\section{THE MOST FREQUENTLY USED SOCIAL MEDIA PLATFORMS IN SPAIN}

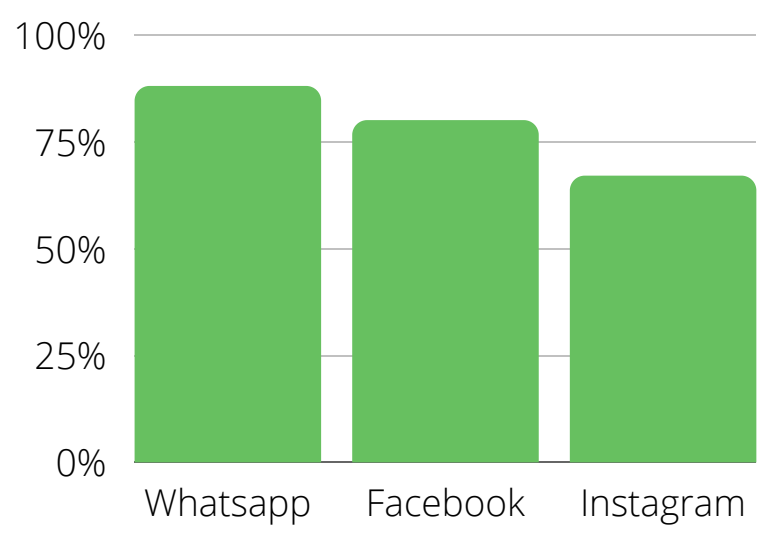

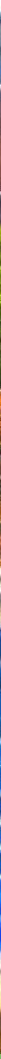




\section{POLAND}

\section{PREFERRED CONTACT CHANNELS}

Polish consumers tend to prefer calling customer service. Polish consumers are too impatient to wait for an answer via email.

In addition to traditional channels, chat and social media are also becoming increasingly popular. Efficiency and speed are the main advantages of these according to Polish consumers. (39)

The favourite contact channels in order:

- Telephone

- Email

- Online chat (live chat \& social media)

\section{PREFERENCE FOR SERVICE}

Polish consumers are known for taking many factors into consideration when making a purchase decision. The brand and the quality of the product are major factors. However, the service they receive during and after the purchase is arguably the most important; they are therefore willing to pay more at a shop which has better service. (40)

\section{THE MOST FREQUENTLY USED SOCIAL MEDIA PLATFORMS IN POLAND}
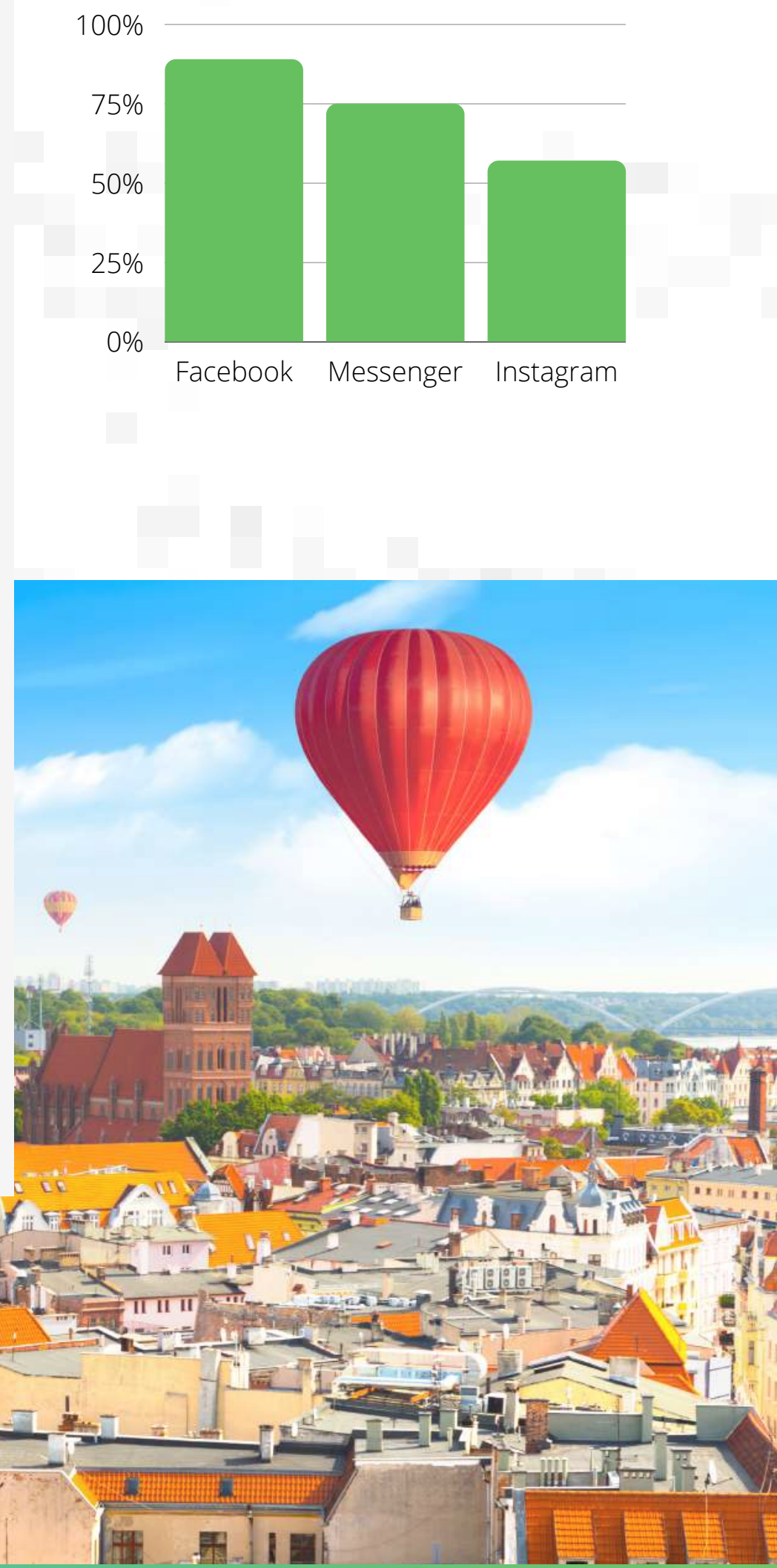


\section{佯 UNITED STATES}

\section{PREFERRED CONTACT}

\section{CHANNELS}

In the United States, consumers prefer to be contacted by phone, with $65 \%$ rating this

option as their favourite. Email comes next with $43 \%$, followed by online chat options (39\%).

\section{SOURCES OF IRRITATION IN CUSTOMER SERVICE}

- $40 \%$ it takes too long to resolve my problem

- $33 \%$ being kept on hold

- $30 \%$ having to repeat the question to different agents
WHAT DO AMERICAN

\section{CONSUMERS VALUE MOST?}

- 61\%: Friendliness and helpfulness of agents

- 48\%: Prompt service with a good solution

- $36 \%$ : Being kept informed during every step of the process

THE MOST FREQUENTLY USED SOCIAL MEDIA PLATFORMS IN THE US

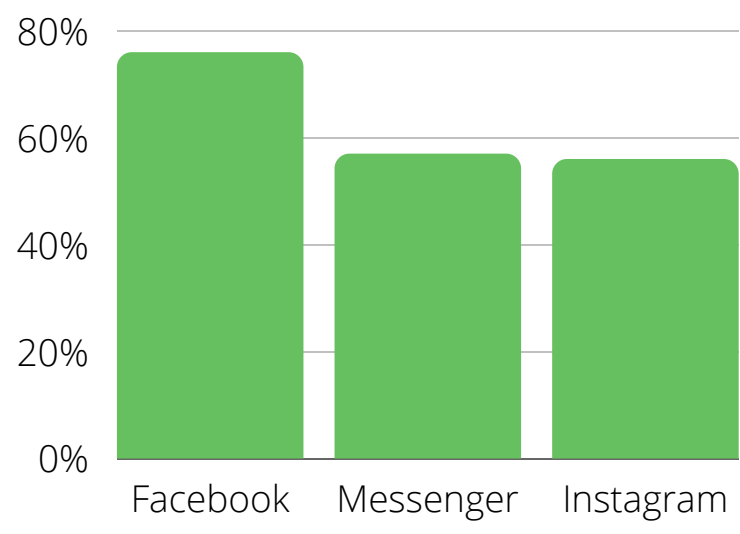

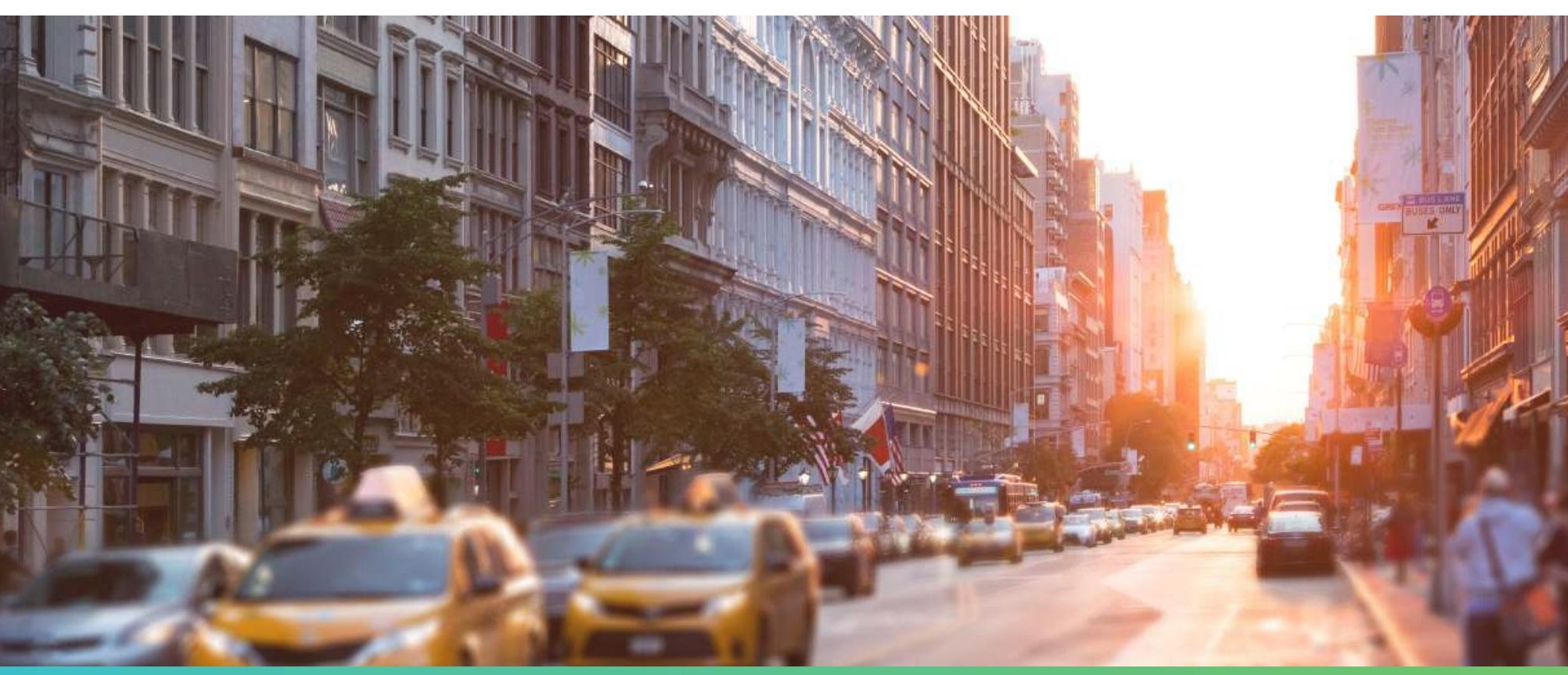




\section{ENDNOTES}

1) Salesforce. (2020). State of the Connected Customer 4 th edition.

https://c1.sfdcstatic.com/content/dam/web/en_us/www/documents/research/salesforce-state-of-theconnected-customer-4th-ed.pdf

2) Amaresan, S. (2021, January 5). 12 Data-Backed Reasons Customer Service Is Key to Business Growth. Hubspot. https://blog.hubspot.com/service/importance-customer-service

3) Grof, S. (2020, June 1). Why Good Customer Service is Important. Our Insight.

https://www.ameritasinsight.com/employee-benefits/industry-buzz/why-good-customer-service-isimportant

4) the right SIZE. (2020, March 20). Omoda lanceert personal shopping service. https://therightsizemagazine.nl/omoda-lanceert-personal-shopping-service/

5) Siders, S. (2020, January 9). 14 Technology \& Electronics Brands Amping Up Online Sales. The BigCommerce Blog. https://www.bigcommerce.com/blog/technology-electronics-ecommerce-design/\#best-technologyelectronics-ecommerce-brands

6) Digital Imaging Reporter. (2020, December 9). Precision Camera \& Video: Digital Imaging Reporter's 2020 Dealer of the Year. https://direporter.com/dealer-of-the-year/precision-camera-video-digital-imagingreporters-2020-dealer-year

7) Retail TouchPoints. (2020, January 10). Tenth Street Hats Tries On AR, Boosts Conversion Rates 33\%. https://retailtouchpoints.com/features/retail-success-stories/tenth-street-hats-tries-on-ar-boostsconversion-rates-33

8) Yieldify. (2020, September 11). Fashion eCommerce: 9 Trends to Capitalize On In 2021. https://www.yieldify.com/free-guides/fashion-ecommerce-trends/

9) Team@Designhubz. (2020, May 12). Place-Visualize-Buy: How Augmented Reality Is Reshaping the Online Furniture Industry. Designhubz. https://designhubz.com/augmented-reality-in-furniture-industry/

10) Faull, J. (2019, July 2). Conversion rates triple when L'Oréal uses AR tech to showcase products. The Drum. https://www.thedrum.com/news/2019/07/02/conversion-rates-triple-when-l-or-al-uses-ar-techshowcase-products

11) Statista. (2021, January). Fashion worldwide. https://www-1statista-1com100019fr400ee.stcproxy.han.nl/outlook/244/100/fashion/worldwide\#market-onlineRevenueShare

12) Statista. (2021, January). Electronics \& . https://www-1statista-1com100019fr400ee.stcproxy.han.nl/outlook/245/100/electronics-media/worldwide\#market-onlineRevenueShare

13) TechSee. (2020). 2020 Survey: No Fault Found Product Returns. https://techsee.me/wpcontent/uploads/2019/04/NFF_Survey-4.pdfMedia

14) Statista. (2021, January). Furniture \& Appliances worldwide. https://www-1statista-1com100019fr400ee.stcproxy.han.nl/outlook/247/100/furniture-appliances/worldwide\#market-revenue

15) Chan, J. (2020, September 11). Social Customer Service: Lessons from 5 of Our Favorite Brands. Mention. https://mention.com/en/blog/social-customer-service/

16) McCarriston, S. (2020, May 10). Coronavirus: How Nike is letting athletes teach workouts during COVID-19 pandemic. CBSSports.Com. https://www.cbssports.com/general/news/coronavirus-how-nike-is-lettingathletes-teach-workouts-during-covid-19-pandemic/ 


\section{ENDNOTES}

17) Fitbit Help. (2020). Fitbit. https://help.fitbit.com/articles/en_US/Help_article/2279.html

18) Park, J. (2020, March 25). Helping You Stay Healthy During This Time. Fitbit Blog. https://blog.fitbit.com/letter-from-ceo/

19) Statista. (2021, January). Personal Care worldwide. https://www-1statista-1com100019f4joooa.stcproxy.han.nl/outlook/254/100/personal-care/worldwide\#market-users

20) Lodhia, J. (2020, November 27). How Glossier Uses Customer Service to Perpetuate Its Business. Fonolo. https://fonolo.com/blog/2019/10/how-glossier-uses-customer-service-to-perpetuate-its-business/

21) BigCommerce. (2021, January 25). B2B Ecommerce Trends + Interesting Statistics 2021. https://www.bigcommerce.com/articles/b2b-ecommerce/b2b-ecommerce-trends/

22) B2B vs B2C Customer Service Interactions. (2020, May 18). Freshdesk Blogs.

https://freshdesk.com/customer-service-skills/customer-service-interaction-blog/

23) Newberry, C. (2020, October 8). Social Media Customer Service: Everything You Need to Do it Well. Social Media Marketing \& Management Dashboard. https://blog.hootsuite.com/social-media-customer-service/

24) Doyle, K. (2019, December 2). Got Bad Customer Service? How to Complain Well and Get Results. Consumer Reports. https://www.consumerreports.org/customer-service/got-bad-customer-service-how-to-complainwell-and-get-results/

25) A.S.U. WP Carey, KraftHeinz, CCMC, \& The Center For Services Leadership. (2020). Key Findings \& Implications From The 2020 National Customer Rage Study. https://research.wpcarey.asu.edu/servicesleadership/wp-content/uploads/2020/06/2020-RageStudyUPDATEDFINALFORRELEASE.pdf

26) Baer, J. (2019, February 25). 42 Percent of Consumers Complaining in Social Media Expect 60 Minute Response Time. Content Marketing Consulting and Social Media Strategy.

https://www.convinceandconvert.com/social-media-research/42-percent-of-consumers-complaining-insocial-media-expect-60-minute-response-time/

27) Spectrm. (2018). The Messenger Performance Report. Spectrm_Whitepaper_Performance Report_v2.pdf

28) CM.com. (2020). De guide voor Mobile Customer Service. https://www.cm.com/cdn/web/nlnl/file/whitepapers/de-guide-voor-mobile-customer-service-nl.pdf?

utm_source=cm.com\&utm_medium=email\&utm_campaign=Mobile\%20Service \%20Cloud\%20\%20The\%20Guide\%20voor\%20Mobile\%20Customer\%20Service\%20Guide\%20(1)\%20-\%20NL29. Klantenservice Anno 2021. (2021, January 12). CustomerFirst. https://customerfirst.nl/nieuws/2021/01/3klantenservice-trends/index.xml

29) Klantenservice Anno 2021. (2021, January 12). CustomerFirst. https://customerfirst.nl/nieuws/2021/01/3klantenservice-trends/index.xml

30) Kruis, R. (2019, June 28). De customer experience trends in Nederland voor 2019. Emerce. https://www.emerce.nl/knowledgebase/d-customer-experience-trends-nederland-2019

31) Global Web Index. (2020). Flagship Report 2020.

https://www.globalwebindex.com/hubfs/Downloads/Social\%20flagship\%20report\%20Q3\%202020\%20\%20GlobalWebIndex.pdf?

utm_campaign=Generic\%20nurture\%202019\&utm_medium $=$ email\&_hsmi=92167087\&_hsenc $=$ p2ANqtz-80HPnBOylgLx255_j7H8r_BDOIICoP8oVHR04WC_t-ECqRcMcZhe3eP8HQdXn8DoqwKhT_2jio7WtO8e5XPIrLJh7w\&utm_content=92167087\&utm_source=hs_automation 


\section{ENDNOTES}

32) Mitel. (2020). Customer Experience Challenges in Pandemic Times.

https://www.mitel.com/-/media/mitel/file/pdf/resource-center/wp-customer-experience-734987-r2011en.pdf?modified $=20201111223329$

33) Degener-Storr, V. J. (2020, August 24). Dienstleistungen verbessern Schlechter Kundenservice: Die 5 häufigsten Fehler kleiner Betriebe. DHZ. https://www.deutsche-handwerks-zeitung.de/schlechterkundenservice-die-5-haeufigsten-fehler-kleiner-betriebe/150/3099/398068

34) Eptica. (2020). Putting Knowledge at the Heart of Customer Experience.

https://info.enghouseinteractive.com/rs/547-FBA-390/images/ei-emea-uk-fy18-dg-eptica-knowledgestudy.pdf?

mkt_tok=eyJpIjoiTXpBMFlqRTJNVGhsTTJKayIsInQiOiJcLzZET1JaN3lnbFg3R05sQmpzM3BzSmdJblwvY3BYbDV vaERpRUNFZoE2MEducEpSQlZuanZMTXVoQzJJQWdZOjdaZjE5eDR6SzN3ZmlVUTVSRXArb2RPVmZnOXIGeUlC TVYocWhmQm5SalE5VGplNjVXdDBzVExSdG5xbExQY3d1Ino\%3D

35) Greco, G. (2019, February 24). Servizio clienti: i 5 canali essenziali che ogni attività di ecommerce dovrebbe considerare. Shopify. https://it.shopify.com/blog/servizio-clienti-5-canali-essenziali

36) 55\% des clients français prêts à payer pour un meilleur service client | Service\&Sens. (2019, May 18). Service \& Sens. https://www.service-sens.com/55-des-clients-francais-prets-a-payer-pour-un-meilleurservice-client/

37) Statista. (2019, May). Main channels of choice to contact customer service concerning fashion shopping in Spain in 2019. https://www-1statista-1com-100019flz006e.stcproxy.han.nl/statistics/1114868/ranking-ofchannels-favorites-of-attention-to-the-client-of-consumers-of-fashion-on-line-in-spain/

38) Sordo, A. I. (2020, May 20). 6 ejemplos de mala atención al cliente y cómo evitarlos. Hubspot. https://blog.hubspot.es/service/ejemplos-mala-atencion-cliente

39) SMSAPI. (2018). SMSAPI raport 2018. https://www.smsapi.pl/public/files/SMSAPI_raport2018.pdf

40) Santander. (2021, January). Poland: Reaching The Consumer.

https://santandertrade.com/en/portal/analyse-markets/poland/reaching-the-consumers

41) Amaresan, S. (2019, December 26). 40 Customer Service Stats to Know in 2020. Hubspot. https://blog.hubspot.com/service/customer-service-stats 
